\title{
Electoral Democracy in Russia: Trends and Prospects
}

\begin{abstract}
The paper reviews the phenomena of the "party of power" and "administrative resource," which have become an integral part of the Russian electoral system. These said phenomena are considered anti-democratic and informal elements, preventing the consolidation of the democratic electoral system. Practices of federal election, those at the end of 2005 and also the regional of 2006, are coherently discussed. This with the goal to explore the extent and methods of the dispersion of the said phenomena of the electoral process and the impact of political conjuncture related thereto. Based on the comments established, possible preliminary scenarios of the oncoming election are discussed, in particular that of State Duma in 2007 and certain possible links to the Presidential election in 2008.
\end{abstract}

\section{Introduction}

Modern Russia is often described as a controlled electoral democracy; that is the greatest national achievements in the democratisation process are related to the democratic functioning of the election mechanism, ensuring a legal and peaceful way for the change of powers. There is legislative basis, which provides for democratic procedures of the election process. Citizens are now enabled to express their civil duty, the election takes place in due time and the runners in the election do not question its results. For the first time in Russian history, power receives legitimization from the people. Therefore the election can be regarded as a significant quality feature of democracy, although its qualitative and quantitative parameters fade in the overall context in political regime wherein the election process takes place. Political parties in Russia do not perform the principal policy making function as is the case in the representative democracy; rather they express themselves in politics as certain additional instruments of personalised power. Lastly, the outcome of the party system and its brief historical development is particularly fragmented and unstable; political parties standing in society are weak and the massive electoral behaviour of voters is not settled yet ${ }^{1}$.

\footnotetext{
* Dr. Virgilijus Pugačiauskas is an associated professor of the Political Science Department of the Lithuanian Military Academy. Address: Šilo 5a, LT-10322 Vilnius, Lithuania tel. +370-5-2103569, e-mail: v.pugaciauskas@lka.lt

${ }^{1}$ Sakwa R., Russian politics and society, 3 rd., ed., New York: Routledge, 2002, p. 172-200; McFaul M., "Political Parties" in McFaul M., Petrov N., Ryabov A., Between dictatorship and democracy. Russian post-communist reform, Washington: Carnegie endowment for international peace, 2004, p. 105-131.
} 
The principal purpose of the paper is to review the Russian election practise, which has risen over more than a decade on the basis of an informal phenomena: to review the "party of power" and administrative resource; to analyse the development trends of election system that have emerged and the traditions which have formed in practises of federal and regional elections; and to compare the conformity of the same to the rules of the democratic elections, as well as that based on the study performed to attempt the shaping of the prospects of the oncoming election of 2007 and 2008.

\section{Election Facts}

In such a vast country consisting of 89 federal units, elections on various levels (federal, regional, and local municipal) are an almost everyday Sunday practise, and the elections statistics is particularly impressive: 3,000 elections in 4 years and 20,000 total in 2000 . Two million people or approximately $2 \%$ of the population is related to arranging the workings of the election process in one way or another. With view to preventing the election process from becoming routine, which would have a direct negative impact on the activity of the electors, the efforts since 2006 were taken to implement the so called single election day project, where the election of all levels took place simultaneously: e.g. on 8 October, two federal levels (repeated election to the State Duma), 27 regional and 387 local municipal institution election took place. ${ }^{2}$

The literature of political science names the election of a national level, i. e. the election of the State Duma and presidential one as electoral cycles: the first in 1993, 1995-1996, the second from 1999-2000, the third from 2003-2004; all of them took place within a short interval except for the first one. According to Mr. Vladimir Gelman, a political scientist, it was the second political cycle that has ended the process of the so called constitutive elections and marked the end of political regime transformation process. ${ }^{3}$ Yet one has to note that further steps of a rather radical character with view to strengthen the so called vertical of power have witnessed the instability of the political regime and the further consolidation towards mono-centric power rather than the end of transformation process.

We shall focus chiefly on the electoral practice of various levels which helps to discover the democratic level of the election system, rather than on the technical elements of the election system such as the voting composition structure of the election districts or the election formula. Based on experience of the State Duma and presidential election, one can distinguish two principal phenomena of the Russian election campaigns, such as the "party of power" and administrative resource directly related thereto; the two have become an integral part of the election and have a significant impact on the results of the

${ }^{2}$ Ibidem, p. 24; “Сведения о назначенных выборах”, http://www.cikrf.ru/2/doc_2_1.htm, 20060402. ${ }^{3}$ Гельман В., Второй электоральный цикл и трансформация политического режима в России, $\underline{\text { http:// }}$ www.spb.ru/socio/files/cycle_2s.pdf. 
political competition. On the other hand, it is those specific phenomena of the election system that are the principal indicators causing well-founded doubts regarding the democracy of the Russian election system. In fact, they should not be considered as phenomena of an autonomous character detached from the overall socio-political and public context of Russia.

Before we begin exploring the problematic issues, it is worthwhile to briefly describe the legislative basis of the Russian election process. One must stress that the laws governing the Russian election process are consistent with principal provisions of democratic elections and correspond to the standards of rights and liberties of the election, thus enabling electors to express their will freely. The said practise, or more precisely the consolidation of the election system, has existed since 1999-2000 where institutions of central power have successfully agreed and passed principal laws governing elections. The election laws are further improved and reformed by amending or supplementing certain rules of law. ${ }^{4}$

In fact one can state that such amendments or improvements take place far to often, as many as 13 took place in 2005, including more significantly worth mentioning: the financing of the parties was increased 10 fold; there was a change of the mixed voting system to the proportional one when electing members of the State Duma; the prohibition to form election blocks in elections of all levels; and the representing threshold has been increased by $7 \%$. These amendments are mostly related to the Kremlin political strategy with view to stabilise and strengthen the positions of dominant party, United Russia, and further decrease the number of parties. In the following year, the number of improvements have been initiated by members of United Russia (possibility to vote against all has been eliminated and the procedure of preliminary voting has been reinstated, etc.). ${ }^{5}$ One can assess constant amendments of election laws also as temporary tactical steps inspired by political conjuncture of the "party of power" (effort to insure more favourable conditions before the oncoming election to the State Duma in 2007), which undoubtedly imposed more restrictions and limitations on the field of political conjuncture, even more favourable conditions being set to arrange the election, without an election, by purposely influencing the electors choice. Yet what causes the failure to consolidate the election rules is the disregard of laws, which in its turn witnesses a low legal culture rather than greater or lesser amendments of the legislation.

\footnotetext{
${ }^{4}$ Ibidem; Гельман В., “Создавая правила игры: Российское избирательное законодательство переходного периода”, № 4, Полис, 1997, с. 21-22.

${ }_{5}^{5}$ Федеральный закон “О выборах депытатов Государственной Думы Федерального Собрания Российской Федерации", http://www.cikrf.ru/_3/zakon/zakon51_180505/zakon_51.htm, 200605 12; “Интервью Председателя ЦИК России А. А. Вешнякова журналу “Профиль” от 17 июня 2006 года”, http://www. cikrf.ru/_1/int_vesh_profil.htm, 200605 13; “Общественный интернет-мониторинг и оценка представительной власти России в 2006 году. Результат экспертизы Nr. 1 (изменение законов о выборах”), http://www.indem.ru/russian.asp, 20060326
} 


\section{2. "Party of Power" as an Instrument for Election Politics}

The functioning of the "party of power" is related to the desire of the political elite to implement their strategy in the election. The literature of political science calls it a quasi party, simply put, that is the political organisation which the elite create for a single purpose - not to lose the election. ${ }^{6}$ The appearance of such an organisation, which tends to be most active during the election, is related to the so-called institutional crises of the executive and legislature, i. e. efforts were taken constantly to neutralise and balance the confrontation between the principal political institutions, the President and the Parliament, since President Boris Yeltsin. Yet it was not until the end of the first term of President Vladimir Putin that this purpose was reached and the stable Duma majority has been formed exclusively from the exponents of presidential policy, which also meant integrating the legislative institution into the system of a "vertical of power."

It was the "party of power" throughout the entire Yeltsin governing period that was used as a means to implement political, economical, and the social development strategy of Russia. The main effort was used to improve the reputation of the democratically disposed president intending to implement the democratisation plan of Russia. Thus the "party of power" since the first moments of presence in political life has not become political organisation, wherein modern democratic initiatives are generated and implemented. Furthermore, its instant transformation took the direction and turned out a substantial obstacle to consolidate democracy rather than support it ${ }^{7}$.

Since 1993, several "parties of power" have struggled for member mandate, this established due to the harsh competition between the governing groups. According to Ms. Olga Kristanovskaja, investigator of the Russian political elite, such actions were not premeditated tactics and they would lose votes due to disagreements. Yet this loss was partly compensated by another fact: the "party of power" would reappear for every election under a different name which greatly facilitated the solution of the principal issue, i.e. to mobilise electors within the short term. ${ }^{8}$

The result came, despite the fact that what the ordinary elector knew of the party was that it supported a strong state, was active in combating corruption and criminality, and it had support of Prime Minister Putin. ${ }^{9}$ Another

\footnotetext{
${ }^{6}$ Хенкин С. “Партия власти”: российский вариант”, № 1, Т. 1, Pro et Contra, 1996.

${ }^{7}$ Sakwa R., Russian Politics..., p. 192; Knox Z., Lentini P., Williams B., "Parties of Power and Russian Politics", Problems of Post-Communism, Vol. 53, No 1, 2006, p. 6-7; Голосов Г., Лихтенштейн А., "Партии власти" и российский институциональный дизайн: теоритический анализ", Полис, № 1 , 2001, c. 6-14.

${ }^{8}$ Голосов Г., Политические партии и электоральная политика в 1993-1995 г2. Первый электоральный цикл в России (1993-1996), Москва: Весь Мир, 2000, p. 108-109; Крыштановская О., Анатомия Российской элиты, Москва: Захаров. 2005, p. 159, 160.

${ }^{9}$ Petrov N., "Russia's "Party of power" takes shope", Russia and Eurasia rewiew volume 2, issue 6, 2003, p. $8-9$.
} 
intention of changing names is that there was no force liable to the elector for the deteriorating situation in the state. In the State Duma election of 1999, this irrational position was most active. The political elite in power failed to escape internal conflict (greatly influenced by the weakness of Mr. Yeltsin's power), in designing a political organisation of the election, therefore only two "parties of power" took part in the election: the old one, the Fatherland All-Russia; and the new one, Unity, representing the interests of Mr. Putin, a new and still growing more popular Kremlin leader. The latter having been created two months before the election has successfully attracted electors, which are in favour of new parties, and ensured their sympathy. Having scored $23.3 \%$ of votes, this political organisation, constructed by administrative means, has come second to the Communist Party of the Russian Federation (hereinafter CPRF) and outscored the "party of power" which got $10 \%$ less votes. Yet this scenario of events does not witness a more intense competitive environment for the political race, because after the election a portion of the regional leaders supporting the old "party of power" have supported Mr. Putin and have explicitly stated that the political composition was designed for election purposes only. ${ }^{10}$

Following the 2000 presidential election and the emerging of new political conjuncture, the issue of the "parties of power" has successfully been dealt with having created a single strong political organisation under a new name, United Russia. It ranked the long-term designers and principal participants of the said structures: Mr. Jurij Luzhkov, and Mr. Sergej Soigu. Once president Putin gathered obviously more power, there were no longer reasons to cause conflicts among those in power; furthermore, the Kremlin became the principal player in the oncoming elections and the designer of the agenda. In fact, one should note that there was still an additional version of the "party of power" planned, with view to gather additional votes of those electors who would obviously not vote for the bureaucrats party; this role was taken by the election block Rodina, hastily formed before the very election (on the basis of three parties). ${ }^{11}$

It is due to the above reasons that, in comparison to the former election, the one in 2003 to the State Duma, the list of parties taking part in the election, displays a substantially stronger single "party of power" and the political elite had no choice but to agree and coordinate its activity so that it conforms to the political direction of highly legitimate President. Therefore United Russia has become one of most successful Kremlin "party of power" projects; its leaders, given favourable political conjuncture (stabilised political, economical, and social life of the country), and having unilaterally available substantial administrative, financial, and informational resources (State controlled media) and supported by the popular Mr. Putin, won 222 (out of 450) mandates of members.

\footnotetext{
${ }^{10}$ Colton T. J., McFaul M. J., Popular Choice and managed Democracy: the Russian Elections of 1999 and 2000, London: Routledge, 2003, p. 7; Shevtsova L., Putin `s Russia, Washington: Carnegie Endowmenent for international Peace, 2003, p. 44-46; Макаркин А., ,"Партии власти", Россия в избирательном иикле 1999-2000 годов, Москва: Генфальд, 2000, с. 144-153.

${ }^{11}$ Соловей В., Избирательные темы и окно возможностей для новых субьектов российской политики, http://carnegie.ru/ru/pubs/media/68498.htm, 20060421
} 
Yet it is due to such hypertrophied actions that the outcome of the election was obvious well before the election, and the political competitors were compelled to run under unequal competition. The observer commission of the Organisation for Security and Co-operation in Europe (hereinafter the OSCE) precisely noted this fact in the election report. ${ }^{12}$ One should also note that United Russia demonstrated unity and consolidated political rows after the election, as was different from the earlier political structures of such character. Having listed over a million members in party list and having branches in all regions, it became the dominant political power in the party system. This political force, having reached new qualitative and quantitative parameters, remained the principal and loyal supporter of the Kremlin policy and its leaders have not shown any disposition to develop towards a "normal" party. ${ }^{13}$ That enables one to claim that the "party of power" shall traditionally function in the marathon of the oncoming election. That is a powerful player, capable to employ a vast range of formal, and in particular informal measures, or to put it differently, it remains the principal administrative obstacle to developing political competition.

\section{Administrative Resource - Dispersion of Informal Tradition}

Apart from "parties of power" there is another not formalised phenomenon we come across in the election process, that is, the administrative resource, being illegal or a semi legal method of the elector campaign which is intended to mobilise them and to weaken or eliminate the positions of the competitors. This is a complex socio-political phenomenon, covering a wide context of the election process: the political and economic elite; its relationship to the political parties; special features of elector political behaviour; etc. It is common knowledge that the principal election function is to ensure the fair representation, the presence whereof being among principal democracy requirements, whereas upon universal use of an administrative resource equal competitive conditions are simply violated for all participants of the election race. ${ }^{14}$ One should point out that the Russian scientific literature is increasingly focusing more towards the problems of the phenomenon; meaning that it explores the legal, social, political, and socio-cultural aspects both on the national and regional levels.

We shall first focus on the ways of the administrative resources, which are employed to control elector behaviour. We shall consider the three principal ones: the informational one, manifested by the media use; the official, meaning the use of the official position during the election; and the forced,

\footnotetext{
${ }_{12}$ Pugačiauskas V., "’Power Vertical” in Russia: 2003-2004 Election Cycle Peripeteia”, Lithuanian Annual Strategic Review 2004, Vilnius: Lithuanian Military Academy, 2005, p. 141-158.

13 “Партия "Единая Россия” сегодня”, http://www.edinros.ru/news.html?rid=298, 20060423.

${ }^{14}$ Воронцова А., Звоновский Б., “Административный ресурс как феномен российского избирательного процеса", Полис Nr. 3, 2003, p. 114-124;
} 
meaning direct influence on the will of the electors and forgery of election results. ${ }^{15}$ Activity via modern media (television, radio, and newspapers) is the most common and effective way when influencing the political choice of the elector. According to the results of sociological studies, television is the leader in this respect, i.e. ordinary citizens receive most information on the course of the election and participants from the central state television channels. ${ }^{16}$ However one must point out that in 14 years of election practice, there were no more signs of pluralism and independence in the State owned media. On the contrary, their active stance being manifested through production of political production, mostly on an illegitimate basis such as campaigning (covertly) for a particular candidate and political party. ${ }^{17}$ It is clear that candidates following the Kremlin line and "parties of power" were among those who mostly seized this opportunity.

The official position, being the advantageous starting position when striving for a better advantage, is also used very often due to its effectiveness in particular as regards to the regional election. This method should be as closely related to the recourse to violence of a different form. It is mostly used in statutory organisations (mostly actions recorded in military units), "references" to business structures to take part in the election foundation of a friendly candidate, inclusion of subordinate authorities and economical institutions in the organisation activity of election campaign, etc. ${ }^{18}$

The OSCE commission, having analysed the course of the election to the State Duma in 2003, has stated in the closing part of the report called the recommendation that the principal issue was the administrative resource and it should be dealt with by authorities of federal and regional levels and the Central Election Commission by way of the legislative basis available. The latter should also initiate the performance of monitoring and arrange a study in order to penalise politicians, political parties, and other officers in charge for abusing administrative resources. ${ }^{19}$ According to the data of the official documents of the Central Election Commission and practise, and analysis of the regional election, one can claim that the administrative resource in terms of the principal issue of democratic election is simply ignored.

Political parties with representatives in top levels of federal and regional executives, employ the administrative resource; to put it differently, the administrative resource under the split elite has more or less been accessible not only

\footnotetext{
${ }^{15}$ Мониторинг злоупотреблений административным ресурсом в ходе федеральной кампании по выборам государственную думу Российской Федераиии в декабре 2003 г,. Москва: ПравИздат, 2004, p. 21-24.

16 Задорон И., Средства массовой информации и электоральное поведение россиян. Россия в избирательном цикле 1999-2000 годов, Москва: Генфальд, 2000, p. 268-269.

${ }^{17}$ Панарин И., Информационная война и выборы, Москва: Городец, 2003, p. 145.

${ }^{18}$ Николаев А., Административный ресурс в региональных избирательных кампаниях, Россия. политические вызовы века. Второй всероссийский конгресс политологов, Москва: Российская политическая энциклопедия, 2002, р. 270-271. Смирнов В., Избирательные права российских граждан перед вызивом власных технологий, Россия..., р. 751.

${ }^{19}$ Russian Federation elections to the state Duma 7 december 2003, OSCE/ODIHR Election Observation Mission Report, Warszaw, 2004, p. 27, www.osce.org/documents/html/pdftohtml/1947_en.pdf.html, 2006 09 05. Also see note 15 .
} 
to the "party of power." Yet the policy strengthening the "vertical of power," pursued by Mr. Putin, this having consolidated the political elite, has influenced the character of use of this method. The access channels have been gradually monopolised in the hands of a single political force. The 2003 election serves as the best example again, where the regional elite automatically redirected its electors to join supporters of United Russia, thereby taking votes from the other parties, the CPRF in particular..$^{20}$ On the other hand, what gives the politicians impetus to act this way is the fact that political preferences of the electors are imbalanced, meaning that they fall easy prey to various manipulations, and lastly the potential majority of ordinary electors fails to identify the impact of the administrative resource. In 2000 , only $4 \%$ of the electors interviewed were able to identify with various levels of precision the administrative resource and less than one third $(27 \%)$ had any knowledge or awareness of the existence of the phenomenon ${ }^{21}$.

The fact that the administrative resource still remains one of the principal instruments of the political fight is evidenced by the 2005 election to Moscow City Duma. The participants in the election took great efforts to make public the use of the monopolised administrative resource by United Russia and Mr. Luzhkov, the mayor of Moscow representing the same, as well as to confront him with any small means available. An exceptional, so to speak step, confirms it, where opponents of totally hostile political ideologies, Yabloko, Union of Right Forces, CPRF, and the Russian Pensioner Party united and instituted a Coordinating council, the principal purpose whereof was to monitor the administrative resource and record other violations of law on the election. ${ }^{22} \mathrm{Mr}$. Sergej Mironov, Chairman of the Federation Council, leader of new Russian Party of Life, publicly discussed the use of the means of the administrative character in the election process. The leaders of party in power gave a lot of effort not to get involved in the far-reaching discussions regarding the accusation of political opponents and only issued public statements claiming having used a single administrative resource, the authority of Moscow power, apparently meaning the popularity of Mr. Luzhkov, the mayor, and high merits and his services to the city. In fact, one should agree, that the living standards in Moscow greatly exceed the statistical country average, though it calls for a separate paper whether all of them should be attributed to a politician who has governed Moscow for 14 years. ${ }^{23}$

Yet, such a minimum effort of political competitors could not prevent

\footnotetext{
${ }^{20}$ Макаренко Б. И., "Парламентские выборы 2003 г. как проявление кризиса партийной системы”, Полис Nr. 1, 2004, p. 59; Звонковский В., Сочиокультурные факторы административного ресурса в российских провинциях, Гражданское обшество и политические процессы в регионах, Московский центр Карнеги, Рабочие материалы, Москва, Nr. 3, 2005, p. 48, 51.

${ }^{21}$ Административный ресурс - это “заначка администрации”, http://www.bd.fom.ru/report/cat/elections/ of004407, 20060910.

22 “Подписано межпартийное соглашение о контроле за проведением выборов в МГд. Пресс-релиз ${ }^{15}$ сентября 2005 г., http://www.yabloko.ru/Pres/2005/050915.html, 20060323.

23 “Цой: административный ресурс Москвы: авторитет московской власти”, http://www.rian.ru/politics/ 20050820/41195374.html, 200603 25; Володин В., Москвичи в очередной раз показали, что они хорочо разбираются и в партиях, и в политиках, http://www.edinros.ru/print.html?id=10950, 20060419.
} 
United Russia from employing the usual range of administrative resource means: financial resources; respective social policy pursued by municipality in more active way; and above all state and municipal media, which went all the way to publish material of campaign character. Municipality, and its subordinate enterprises, organisations, and officers making use of their official position, became canvassers and supporters of the "party of power" and organisers of its election process. Obviously, these were the actions that the party management tried to perform covertly and there was no way one or several parties could possibly identify it, let alone establish the exact level of their efficiency. As a matter of fact, the analysts investigating the problems of the administrative resource all agree that the efficiency of this phenomenon should be calculated on the basis of $10 \%-15 \%$ of the elector vote margin. ${ }^{24}$

One must stress that the administrative resource manifested in yet another form, which continues acquiring integral elements of antidemocratic traditions, namely the elimination of political opponents from the election process. The decision of the Moscow election campaign (endorsed by the Court ruling) to eliminate the party Rodina from the election raised justified doubts due to its radical character. It is obvious that one should not regard such a decision in terms of legal means of powerful elite combating with an increasingly spreading racist, xenophobic, migrant phobic, anti-Semitic sentiments and those inducing ethnic discord in public and political life. Firstly, that is only an efficient way to do away with a political competitor, to put it more precisely, the first specific warning from Kremlin politicians to the leaders of Rodina, who attempted to pursue policy not agreed with in a position of central power. Human Rights Organisation, a public organisation, at their Moscow office which monitored the election, has found that in the Russian liberal democrat party of Mr. Vladimir Zhirinovsky, certain candidates of the CPRF and some small parties (Russian Party of Life and Free Russia) have expressed themselves in similar xenophobic manners in the election campaign, yet this did not provoke negative responses from competent institutions and no sanctions were employed in this regard. ${ }^{25}$

Sociological studies again confirm that an ordinary citizen in the capital city, even taking into account the fact that he or she is more politically aware and more critical than the rest of Russian population and finally most of them approve of the democrats, still finds it complicated to identify the impact of the administrative resource use. In the sociological survey by Jurij Levada analytical centre, $28 \%$ of respondents stated that there were no significant violations, and as many as $44 \%$ found it difficult to reply precisely to the question. Yet the majority of electors had a more crystallised view and were able to answer more precisely to the question regarding the political party most likely to ben-

\footnotetext{
24 “Итоги выборов в Московскую городскую думу. Стенограма Х Круглого стола”, http://scilla. ru/works/uprzdem.krst10.html. 200604 05; Also see: "О нарушениях прав избирателей на выборах в Мосгосдуму”, http://www.jabloko.ru/Press/2005/0512042.html, 20060323.

25 "Ксенофобия, мигрантофобия и радикальмый национализм на выборах в Московскую городскую думу", http://www.antirasizm.ru/publ_056.doc, 200604 06; Петров Н., Думократизация, http://www. grani.ru/opinion/petrov/m.99202.html, 20060503.
} 
efit from it: $52 \%$ supported United Russia, and only $23 \%$ failed to reply. ${ }^{26}$ On the other hand, the ability of democratic forces to unite and tackle a high $10 \%$ election threshold witnesses that it is possible to stand against consolidated administrative influence. Yet this situation is not good news, because the percentage of voters in 2003 compared to that in 2005, reveals that both parties got $6.7 \%$ votes less, whereas all the other parties (including the Communists) successfully improved the results. ${ }^{27}$

With view to thoroughly investigate the circumstances and efficiency of use of the Russian election administrative resource, one must take a brief look at the wider context of latest regional election. ${ }^{28}$ The practice of a single Election Day, 12 March 2006 and 8 October 2006, comprised more than half of all country regions, wherein the election of regional legislation and municipal (mayor and council) took place. It should be stressed that agenda of the regional election included usual violations of the democratic election process, in particular the elimination of parties and specific candidates from the election was employed. To that end, the local election commission were employed, also involving judicial institutions, for example 10 out of 23 parties were prevented from taking part in election run of 12 March in 8 regions (in Nizhni Novgorod 7 out of 13 parties were eliminated, meaning not registered or eliminated in course of election process) due to violations of legislative procedures: violations in gathering residents signatures; violations of nomination procedures of candidates in parties; and failure to submit documents necessary for registration purposes. ${ }^{29}$

Yet there are few circumstances posing doubts whether the regional election commissions have complied with the law on election at all times. By the way, speaking of an administrative licence ("административные перегибы" in Russian), one means a negative application or loose interpretation of rules of the laws on the election by the election commissions, law, and order institutions and the courts. These actions have become almost a usual component of the everyday election agenda, in fact, even Mr. Aleksandr Veshniakov, the head of the Central Election Commission has stated publicly himself on it as an evident issue of the election process ${ }^{30}$.

Firstly, what makes selective party selection performed suspicious is the fact that mostly the same parties find themselves among those in violation of the registration procedures, e.g. Agrarian Party of Russia, Social Justice, Russian Patriots, Iabloko, and Rodina in particular. Secondly, in Rodina the case it is obvious that party elimination from the election process rate accelerated in the election of 12 March. It topped the list of those in violation of the election order,

\footnotetext{
26 “ Москвичи об итогах думских выборах”, http://www.levada.ru/press/2003011900.html, 20060203.

${ }^{27}$ Маслов О., Прудник А, Скрытие итоги выборов в Московскую городскую Думу и их влияние на последующие выборы в России, http://www.polit.nnov.ru/2006/02/15/mosgorduma/, 20060526.

${ }^{28}$ Петров Н., Титков А., Региональное измерение выборов, Россия в избирательном иикле...., p. 400.

29 “Доклад секретаря ЦИК России О. К. Застрожной”, http://www.cikrf.ru/_1/dok1_zasrojn 0906/dokl zasrojn_090606.htm, 20060409.

30 “Интервью Председателя ЦИК России А. А. Вешнякова газете “Ведомости", http://www.cikrf. ru/cikrf/aboutcik/charmain/int vesh 220306.jsp, 20060410.
} 
being prevented from taking part in 7 out of 8 regional elections. Where the management of the party attempted objecting the Kremlin's intention to unite several parties, Mr. Dimitry Rogozin, party leader who was totally opposing such idea, resigned from the managerial position being aware that he shall not be in a position to oppose the Kremlin. ${ }^{31}$ Yet, following the resignation of the rebellious politician, no obstacles remained to run the election and the new management eagerly took on the new Kremlin project, i.e. the joining of the three parties (Rodina, Russian Pensioner, and Russian Life parties). ${ }^{32}$

The issue of the administrative resource in this election was practically excluded from public discussion by all local institutions competent in the election organisation, the Central Election Commission, in charge of control of performance of election law, even opposition parties. Only violations recorded by the observers were established and the press showed very little interest ${ }^{33}$. The examples show witness that the regional political elite considers the administrative resource essential, rational, and even semi legal (inspiring no legal consequences) action of the election process and the representatives of the "party of power" increasingly monopolise the same in their grasp. One can therefore state that the trend to narrow the field of political competition has not only remained, it has even grown stronger.

The results of this election illustrate a clear setting of political forces, which given stable political conjuncture, should not radically alter in the nearest future. United Russia came out as the favourite of the 12 March election: $55 \%$ members mandates in 8 regional parliaments (197 out of 359), and 8 October - in 9 parliaments $53.9 \%$ respectively ( 244 out of 446 ). The Communists retained second place, by gaining $11 \%$ and $6.8 \%$ of elector votes respectively. The remaining votes were taken by the Party of Life, Russian Pensioner Party, Rodina, liberal democrats headed by Mr. Vladimir Zhirinovsky, and other small parties. The principal opposition democratic parties, Iabloko and the Union of Right Forces in the first day election were able by chance to take part in 3 and 4 regions respectively, and in the second one, only a party headed by $\mathrm{Mr}$. Grigorij Yavlinski (in 3 regions), although the democrats faced total fiasco by failing to step to the $7 \%$ election threshold. ${ }^{34}$

In fact, in Karelia, where this party has traditionally enjoyed wide support, it was simply eliminated from the election. ${ }^{35}$ These examples demonstrate the inability of democratic forces to develop the agreements reached during the

\footnotetext{
${ }^{31}$ See: note 29; "Рогозин: Меня хочет сместить власть. И мне об этом сказано прямо" http://www. rodina.ru/interwiew/show/?id=473, 20060406.

32 “Тезисы выступления А. М. Бабакова на внеочередном съезде партии “Родина", http://www.rodina.

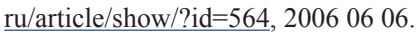

33 “Административний ресурс делили почту пополам между “Единной Россией” и “Партией Жизни”, Родная газета, 26102006.

${ }^{34}$ Интерфакс, Глава ЦИК Вешняков “Единая Россия” победила на выборах всех девяти регионах", 09 10 2006, http://www.main.fci.ru/index.cfm, 200605 23; ЦИК, Интерфакс, “Единая Россия" победила на восьми региональных выборах, 1303 2006, http://www.main.fci.ru/index.cfm, 200605 23. Машкин М., “Полупраймериз. Девять регионов готовы явится к урнам”, Независимая газета, 20061006.

${ }^{35}$ Пресс-служба, О нарушении избирательных прав граждан в Республике Карелия, 6 октября 2006 года, http://yabloko.ru/Press/Docs/2006/1019-karelia.html, 200604 29. Also see note 31.
} 
election to the Moscow Duma regarding joint actions. It is therefore no surprise that these parties suffered expulsion to the margins of political competitions. Therefore the practical examples from the election of Moscow, the mega city Duma, and regional legislation institutions, do not give basis to await at least the minimum changes towards the democratisation of elections at least in the nearest future.

One can state with confidence, that issues of administrative resource dispersal have remained an acute issue of the election process still not dealt with, and the impunity of the activity provides for ideal conditions for spreading political corruption. It is important to state that neither the top level officials, nor institutions charged with the election process, deliberately deal with such deeply rooted totally opposite tradition to rules of the democratic elections.

\section{Scenarios of the Election Prospect}

The prospect of the oncoming election, in particular that of 2007 State Duma and certain possible connections to 2008 presidential election, shall be discussed in this case in narrow context on the basis of experience and of the election readily held - the phenomenon of the "party of power," the administrative resource, the changing role of opposition in the political system, and obviously in the context of the policy pursued by the Kremlin. It is also obvious that the dynamics of the political situation within a year before the first election can easily destroy the forecasts (as has happened before on many occasions) based both on theoretical and empirical insights.

There are no greater doubts today that the "party of power" shall remain the principal means in the Kremlin strategy enabling one to ensure the continuity of the general policy line of the executive. One can only add that the Kremlin policy makers have initiated preliminary preparation for the oncoming elections. This with view to ensuring favourable positions, and to protect themselves from possible surprises, they engaged in setting additional scenarios of party of power. Therefore it is worthwhile to explore thoroughly the circumstances of this political decision, even more so because of the fact that the leaders of United Russia commented this news publicly rather carefully, without much enthusiasm. ${ }^{36}$ However, there is no big deal in this matter. It is clear that the technologists of the election process, when designing a new election strategy, directly rely on the experience drawn from the previous election, to be more precise, they have employed some of the scenarios used in the federal election which have shown to be time-proven. In the 2003 election to the State Duma, Rodina can also be attributed the role of the second "party of power."

One can state that the foundation of the new party, bearing the unusual name Fair Russia: Fatherland, Pensioners, Life does not pose a greater risk of

\footnotetext{
36“Первый вице-спикер Госдуму Олег Морозов - о новой партии власти”, http://www.morozowov. ru/index.php?id=637, 20060910.
} 
splitting the elector votes due to two important tactical motives. Firstly, according to the Kremlin design, the principal task of the election political organization was to attract elector votes from CPRF, the principal competitor; regional election and sociological surveys also support this view. The new "party of power," headed by Mr. Mironov, a politician loyal to Mr. Putin, announced its principal program purpose, socially headed fair state, and the press called this single project real left. ${ }^{37}$ Secondly, the new party will be supported by those who potentially are not happy with the policy pursued by United Russia for one reason or another. With view to these factors and keeping in mind the fact that elector is not yet able to resist the magic of the new party names, and the administrative resource shall become principal means, one can speculate that this election organisation shall collect more votes than necessary to pass the election threshold.

Therefore parties of power have begun thorough preparation for the oncoming election and the results of the interim election suggest that the other political forces shall face an unusually hard battle given the unequal conditions. One can firmly state that the Kremlin, with just one year before the election, is finally ready to deal with issue of power in the 2007 traditional way with the aid of "parties of power." The President, supported by the two powers, has more room for political manoeuvre and is prepared whereas the first party fails to get necessary majority of the electors.

It is rather complicated to define the prospect of the 2008 election beforehand, in particular on the basis of former experience of the election process only. Therefore it is only possible to name certain assumptions or simply a few possible scenarios. With still two years still to go before the election, President Putin has publicly announced that no amendments in the Constitution regarding the extension of a presidents term of office shall be made. Thereby he has only partially revealed his position, though it still will remain in question the way the principal issue shall be dealt with. Today the governing elite, at least externally, are gathered in the President's political force field, i.e. it is not affected by open and deep conflicts as compared to the era of Mr. Yeltsin. Most of them, including regional leaders, attempt to retain status quo and that is the principal challenge, i.e. to ensure the coming of new Kremlin teams in a way following the policy line pursued by Mr. Putin for 8 years. However, stepping aside from the strong political figure opens better chances for new configurations of the governing elite in the battle for the central office of power; particular politicians shall no doubt have benefited from it, therefore there are some assumptions of public conflict.

As the election date draws closer, Mr. Putin is obliged to be more open about the construction design of his political process. Most recently the president has stated that by being legitimated by the society, he shall be able to influ-

\footnotetext{
37 “Программное заявление партии “Справедливая Россия: Родина, Пенсионеры, Жизнь”, http://www. rodina.ru/article/show/?id=567, 200609 14; Серова Я., Раздвоение партии власти. Победу празнуют как “ЕдРО, так и “актуальные левые”, http://2006novayagazeta.ru/nomer/200678n/n78n-s16.shtml, 20060912.
} 
ence the processes underway in the country. This has only contributed to the rising temperature of imagination among the public and also political scientists in particular. Nothing was said about the fact that having resigned, and only relying on trust, the political force should can be maintained and enforced. High legitimization by the society is an effective means only given specific political post and there is only one significant office in Russia, the President.

Therefore, in order to remain the actor dealing with state matters, at least two points are necessary: the new president has to be bound by links of total dependency; and secondly, he has to take direct part in the policy, in one of its forming institutions. More recently, Russia saw an active discussion of the version whereby Mr. Putin could relate further retaining of force, by way of political party instrumentation, i.e. party prospect being related to United Russia, by attributing to the same exceptional role (that of dominant party) in the party system. It is this party that is most likely to become the principal means whereby it will be attempted to deal with the issue of 2008 and to ensure continuity of the executive in the long run. ${ }^{38}$

In fact, even prior to the public announcement one can see that the activity rate rising in party actions and manifesting itself via an active regional election campaign, and statement of Mr. Boris Gryzlov to the effect that the party shall dominate its candidate to 2008 presidential election, this further induces to view this event scenario as real. ${ }^{39}$ The fact that the party is able to gain a dominant party position in the nearest future is evidenced by the sociological insights based on precise empiric. And these claim that the society wants to consolidate in the structures of majority power. The present political structure, impossible to identify given political ideology, meets best the need of society still mixed between the ideas of the left and right. It is able to gain sympathy of vast masses by accumulating wide range of ideas (it liberates the elector from independent ideological determination). ${ }^{40}$ Yet only the oncoming events shall verify the future scenario reality even that based on strongest arguments.

What is clear today is that, independently of mechanisms to be chosen to implement this complex political construction, the issue of new president shall not be entrusted to the society in the competitive democratic elections. It is most likely, both theoretically and practically, that the election shall take place according to the usual Russian order of democratic election where ordinary citizens are easily swayed by manipulative means and shall be mobilised to approve a decision given to them from above.

Considering the possibilities of the democratic opposition forces to be

\footnotetext{
${ }^{38}$ Гельман В., “Перспективы доминирующей партии в России”, Pro et Contra, No. 4, 2006, c. 62-71; Мигранян А., Преемником В., "Путин а может быть сам В. Путин, Известия, 2006; Rusijos Federacijos Prezidento administracijos vadovo pavaduotojas Vladislavas Surkovas iškėlè valdžios partijai uždavinį per 10-15 m. užtikrintị dominavimą partineje sistemoje. Plačiau žr.: "Политический процесс будет строиться вокруг “Единной России”, http://edinros.ru/news.html?id=114850, 20061029.

39 “Единная Россия" будет предлагать своего кандидата на президентских выборах 2008 года", http:// edinros.ru/news.html?id=114118, 20061030.

${ }^{40}$ Бызов Л., Потребитель стабильности (о феномене (“Единой России”), http://www.politnauka. erg/library/parties/byzov.php, 20060915.
} 
part of political elective institutions, one must state that there is no positive development in this field. It is sad that the democratic forces did not find the impulse in the Moscow Duma election lesson to strengthen one's position and carry on qualitative reforms. Regional elections are yet another more obvious example witnessing that society is not yet ready to support the democratic forces more actively and the latter are not capable to adequately react to an adverse situation. It was the 2003 Duma election that demonstrated more obviously that ordinary elector has related all single country failures with democratic political forces. ${ }^{41}$ Given this adverse situation, there is only one way out - to combine efforts in the fight for elector support.

Yet when analysing public statements and the latest program documents of political parties, it became clear that the politicians calling themselves democrats underestimate the impact of inactivity, they are not capable to transcend or to tackle the patterns of their inert thinking, and above all, personal ambitions. According to the long standing politician Mr. Anatolij Ciubais, the Democrats form separate, independent pillars: Mr. Grigorij Yavlinski, Mr. Vladimir Ryzhkov, Mrs. Irina Chakamada and the Union of Right Forces ${ }^{42}$ As a matter of fact, Mr. Ciubais, like Mr. Nikita Belych, the current party leader, attempts uniting democratic forces and takes part in the oncoming election in the single list, though that is not the case with other leaders' ${ }^{43}$

There is no time for lengthy theoretical discourse and hollow political rhetoric, whereas the "party of power" strengthen their positions by taking part of the ideas and electors from the democrats, and increasingly monopolising the administrative resource field. On the other hand, a proportional election system introduced simply induces parties to work in the regional level more efficiently in order to ensure substantial support in national election. Therefore it already is today, that one can claim the prospect that democrats are being not highly productive. Firstly, these forces have failed to arrange and mobilise themselves in a short period of time, that is to say that they shall not be properly prepared for the important election. Secondly, unless they unite, they cannot expect to pass the election threshold in the oncoming State Duma election.

\footnotetext{
${ }_{41}$ Gelman V., "Political Opposition in Russia: A Dying Species?", Post-Soviet Affairs, 2005 21-03, p. 4, 12.

42 “Анатолий Чубайс: Объединение правых с левыми - это забавный союз бессмыслености и безумия”, http://sps.ru/?id=216972, 20060607.

${ }_{43}$ Емельянова Н., Комерсант: На ІІ конгрессе демократических сил Перми было подписано согламение о сотрудничестве, http://www.sps.ru/?id=216539, 200606 07; Белых Н., Нам основной политический опонент - это партия власти “Единая Россия", http://www.sps.ru/?id=206905, 20060607.
} 


\section{Final Comments}

There is little risk to be wrong when stating that, despite Russian laws governing the election process being relatively democratic in formal terms, the phenomena that has formed and is deeply rooted in the election practice, such as "party of power" and the administrative resource, along with the way that they occur, shall remain the principal means of the political elite in power, in the competition battle. There is therefore very little doubt that the oncoming national election will witness the violation of a fair election. That shall not be affected by neither the situation before the election in the country, nor party system fragmentation level, nor the level of the elector activity, and or other similarly important factors. It is therefore hard to expect that the election in the nearest future shall set an example of democracy consolidation. 